\title{
DÜBLIN
}

Technological University Dublin

ARROW@TU Dublin

\section{Implementing eCommerce in the Irish Construction Industry}

\author{
Alan V. Hore \\ Technological University Dublin, alan.hore@tudublin.ie \\ Roger West \\ Trinity College, rwest@tcd.ie
}

Follow this and additional works at: https://arrow.tudublin.ie/beschreccon

Part of the Construction Engineering and Management Commons

\section{Recommended Citation}

Hore, A.V. and West, R.P., (2008), Implementing eCommerce in the Irish Construction Industry, ECPPM 2008, eWork and eBusiness in Architecture, Engineering and Construction Conference Paris, 9th-12th September 2008, Edited by Zarli A. And Scherer, R., CRC Press, pp.605-612. doi:10.1201/ 9780203883327.ch68

This Conference Paper is brought to you for free and open access by the School of Surveying and Construction Management at ARROW@TU Dublin. It has been accepted for inclusion in Conference papers by an authorized administrator of ARROW@TU Dublin. For more information, please contact arrow.admin@tudublin.ie, aisling.coyne@tudublin.ie,gerard.connolly@tudublin.ie.

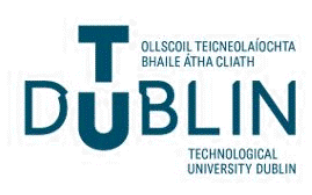




\title{
Implementing eCommerce in the Irish Construction Industry
}

\author{
A.V. Hore \\ Department of Construction Economics and Management, Dublin Institute of Technology, Bolton Street, \\ Dublin, Ireland
}

R.P. West

Department of Civil, Structural and Environmental Engineering, Trinity College, Dublin, Ireland

\begin{abstract}
The current methods of ordering, delivering and invoicing of materials in the construction industry is enormously inefficient, with vast quantities of paperwork, duplication of effort, scanning, re-keying and resolving mismatches between invoices, delivery dockets and purchase orders. The objective of this paper is to set out the progress that is being made by the Construction IT Alliance (CITA) in Ireland to support the implementation of eCommerce in the Irish construction industry. The authors will present the result of a pilot project in 2006 which demonstrated that the technology necessary for implementing an electronic supply chain exists and could be deployed successfully in the construction industry. The authors also outline the expected results following the recent setting up of a dedicated eCommerce group by CITA to provide independent advice and support to the members that are embarking on implementing eCommerce. An additional expected result outlined by the authors includes the implementation of a standard data pool to facilitate the interoperable exchange of product codes between trading partners.
\end{abstract}

\section{INTRODUCTION}

Over recent decades, industry generally has come to recognise the inefficiencies that exist in paper-based systems. Many sectors of industry have replaced their paper-based systems with electronic systems. The construction sector, however, lags behind other business sectors in harnessing the greater potential of Information Communications Technology (ICT) (Thomas and Hore, 2003; Gunnigan et al., 2004; Hore and West, 2005a).

Building materials can account for up to $50 \%$ of all costs on a typical construction project (Tavakoli and Kakalia, 1993). There are many millions of trading documents produced by both main contractors and suppliers, such as purchase requisitions, purchase orders, delivery notes, supplier invoices, supplier statements and remittance advice notes (DoF, 2002). Each of these documents has to be rekeyed individually as they pass between different locations and computer applications (Hore et al., 2004).

Apart from the obvious inefficiencies of this process, there is also a high risk of error, and in the case of documents such as PODs (Proof of Delivery), a figure of $25 \%$ of PODs lost on construction sites is not an uncommon figure. The retail and electronics industries have been using an electronic supply chain exchanging various documents for twenty years or more, but the construction industry has been slow to adopt this technology, mainly because of the nature of the work undertaken, and the temporary nature of construction sites.

This paper will present the methodology and results of a pilot project which sought to re-engineer the purchasing process, by seeking to adopt a fully integrated ICT solution, which achieved a dramatic improvement in the overall levels of productivity with subsequent cost reduction. The paper goes on to describe the expected results following the recent setting up of a dedicated eCommerce group by CITA to provide independent advice and support to the members that are embarking on implementing eCommerce.

CITA is an organisation dedicated to the promotion of best practice in the use of ICT in the Irish construction industry. It was established originally by the Dublin Institute of Technology, but has since evolved into a company limited by guarantee with a membership of over 140 organisations drawn from main contractors, suppliers, architectural practices, 
quantity surveyors, engineers, project managers, and third level institutions.

\section{TRADITIONAL CONSTRUCTION MATERIAL PURCHASING PROCEDURES}

The traditional process of procuring materials in construction is dependent on a number of factors. For example, the size of the project, size of firm, organisation structure of the firm and the roles and responsibilities of the employees within that organisation can dictate purchasing procedures. The process typically involves both centralised and decentralised personnel. The sophistication of the process varies widely, with many of the more established firms possessing company manuals detailing the procedures and standard forms that staff should adopt (Canter, 1993).

Figure 1 depicts an outline of the material purchasing process during the construction stage.

Figure 1. Traditional material procurement process

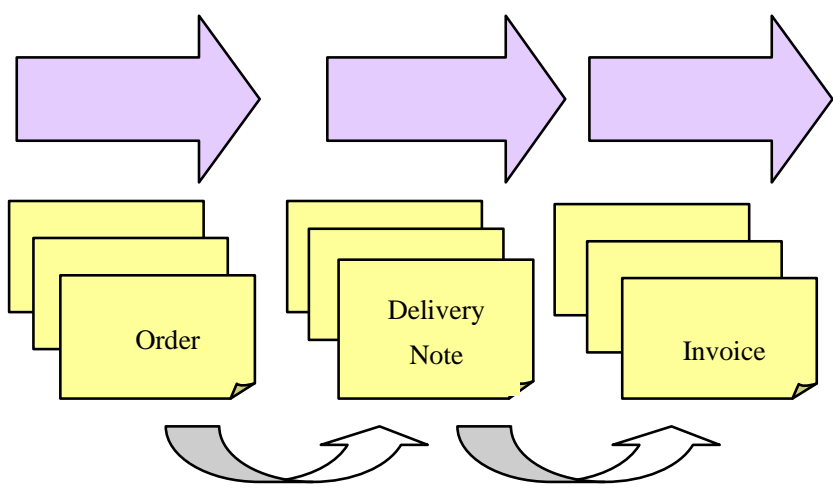

Purchasing procedures typically involve a paperbased communication process between the purchaser and supplier. It invariably involves the raising of a purchase order (PO) to the supplier. On delivery of the materials to site, a delivery docket is signed by the contractor and forwarded to head office as proof of delivery. Payment of the invoice will be made following the matching of the invoice to the original purchase order and signed delivery docket.

Classic purchasing processes in construction are paper-based, where documents are used to create other documents. As a result, the probability of an error increases as information is transcribed from one document to another. Although paper documents can be inputted into a computer system, data entry requires multiple transcriptions of the data. As a result, such processes can result in the introduction of additional errors into the system (Hore and West, 2005b). Paper-based systems also are dependent on ensuring that all appropriate departments get copies of the documents necessary to do their job. If even a small percentage of those documents become lost or misplaced, there can be gaps and delays in the system (O'Leary, 2000).

\section{THE PILOT PROJECT}

The overall aim of the pilot project was to reengineer the purchasing process within a contractor's organisation, by enabling an electronic threeway match of the PO, delivery docket and invoice data, thus enabling a significant improvement in both productivity and overall administration costs per transaction.

The methodology involved using the reengineering methodology designed by $\mathrm{Li}$ (1996). Li suggested that at all stages in the re-engineering process it was important to introduce an experimental loop, in order to ensure the progression of problem solving during the re-design of the business processes. This methodology is illustrated in Figure 2.

Figure 2. Re-engineering methodology adopted in 2005 pilot project (Li, 1996)

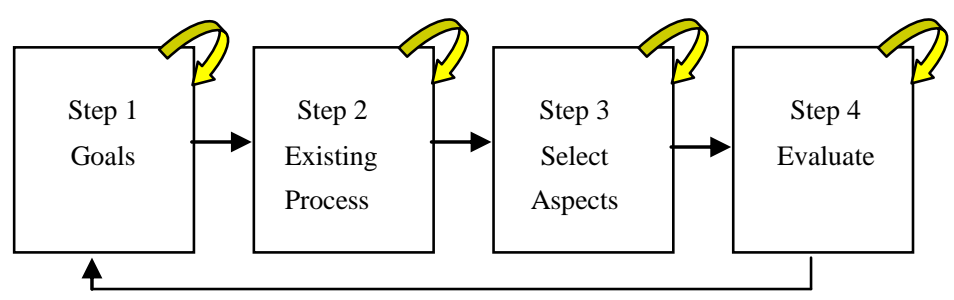

The process designed by Li (1996) involved four core stages, namely:

Stage 1 - Set goals for re-engineering - This stage involved the setting of clear and measurable objectives at the outset of the re-engineering process.

Stage 2 - Analyse existing processes and its operational boundaries - In analysing the existing process, focus was directed to understanding the problems and inefficiencies that existed within the contractor's business process.

Stage 3 - Select aspects of the existing process to redesign - Fundamentally, the re-engineered solution devised by the authors involves a fully electronic, three-way electronic match of the PO, delivery docket and supplier invoice, minimising as many of the existing identified inefficiencies as possible, while solving any new problems that may arise. In this, the focus was the source of the PO information was singled out in re-designing the process. In addition tasks and activities that did not add value to the business process and were costly to administrate were simply removed.

Stage 4 - Implement and evaluate the new process - It was important that the new process was 
tested for a reasonable period of time. Results from the new process were collected and the evaluation of the results indicated that the re-engineering goals were achieved, as shall be shown.

The pilot project sought to identify goals, in order that a technological solution to the problems would effectively re-design and re-organise the purchasing process, which would lead to a worthwhile and tangible improvement in the performance and competitiveness of both trading partners. The specific goals identified by the pilot team included:

1. To document the current trading procedures utilised within the contractor's organisation.

2. To identify the inefficiencies that currently exists within the contracting organisation.

3. To re-design the purchasing process with a view to addressing the inefficiencies that currently exist.

4. To document the proposed trading processes and the ICT support infrastructure to be utilised between the contractor and the supplier on the intended pilot project.

5. To execute the proposed re-engineering process on a live project.

The authors carried out a detailed examination of the contractor's existing purchasing process. This involved mapping the process flow charts for the material ordering, material receiving and invoice processing. Following the completion of this exercise it was evident that many inefficiencies existed in the current process adopted by the contractor, namely:-

- Manual reliance - Most (if not all) of the purchasing process was manual, with little to no reliance on technology.

- Matching inefficiency - Two/three way matching of items leads to re-handling of paperwork many times until matching occurs, which increases the probability of errors occurring between the various documents for single transactions

- Deficient supplier information - Personnel can only collect a limited amount of information about suppliers and their products through the collection of physical catalogues. The catalogues, in turn, are cumbersome to use, require large storage areas and can quickly become outof-date.

- Poor integration - The paper-based system was also dependent on ensuring that all appropriate departments obtain copies of the documents necessary to do their job. If a small percentage of those documents are delayed, lost or misplaced, there will be delays in the payment process as a whole.

In re-designing the contractor's purchasing process, it was necessary to look in detail at the remaining weaknesses in the process and identify the electronic opportunities to remove these weaknesses. The key to the solution was to allow the supplier to create the PO data, as opposed to the traditional role of the contractor creating the PO. By allowing the supplier to create the PO, delivery note and the invoice information, the problem of the three-way electronic match was much more likely to be solved.

The re-engineered process included a minimum amount of manual work to be carried out. This was limited to the creation of the Open Order, the necessity to approve the PO Confirmation and the electronic signature of the handheld device. There was no necessity to photocopy extensively or print documentation other than to receive the Open Order details initially. There was a requirement to allow interrogation of the Enterprise Resource Planning (ERP) system with limited re-keying of information with respect to PO, delivery note and invoice confirmations.

The proposed ICT infrastructure to be adopted involved the electronic transfer of PO, delivery notes and invoices via a central HUB. Figure 3 illustrates the ICT infrastructure.

Figure 3. Proposed trading process and ICT infrastructure

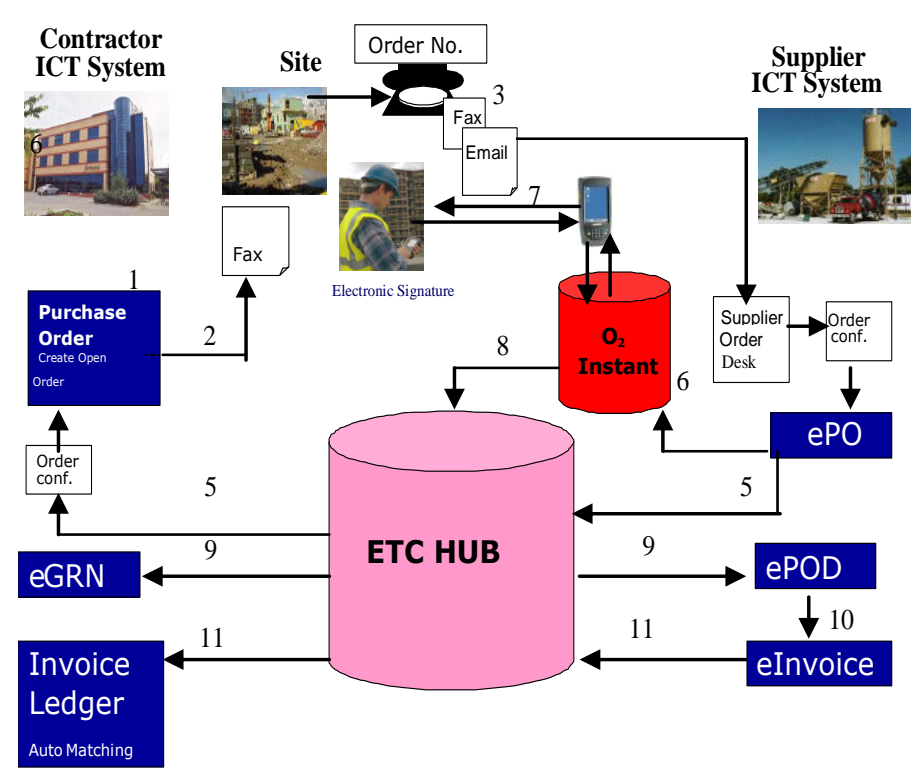

The HUB was able to convert any incoming EDI, XML or spreadsheet documents from either the contractor's ERP system or the supplier ERP system into a format suitable to the particular receiving ICT system.

The proposal adopted involved the trading parties creating an Open Order in the contractor's ERP 
system (Step 1). In advance of this communication, the contractor would have negotiated a schedule of prices for particular products from the supplier. The proposed process created an automatic fax to site detailing a unique PO number (Step 2). The open order authorised site personnel to order materials by telephone, fax or email to the supplier (Step 3). The key difference between the initial proposal and the proposed solution was the fact that the supplier created the Electronic Purchase Order (ePO) information, not the contractor, as in the initial proposal (Step 4). The ePO was electronically sent to the HUB. The HUB converted the data into a XML message, which, in turn, is forwarded to the contractor's back-end database and populates a line item on the contractor's purchasing workbench (Step 5).

The ePO created by the supplier was dispatched to the $\mathrm{O}_{2}$ Instant repository, which, in turn, routed the message to a handheld computer (Step 6). The supplier delivered the material to site and the contractor electronically signed the Personal Digital Assistant (PDA). The ePO is routed back to the $\mathrm{O}_{2} \mathrm{In}$ stant repository (Step 7) and onto the HUB to verify proof of delivery (Step 8). The ePOD is routed to both the contractor's and the supplier's back end database and populates line items in their respective ICT systems, thus creating an Electronic Goods Received Note (eGRN) (Step 9). The receipt of the ePOD in the supplier's back-end system, will allow the supplier to create an eInvoice from the ePOD and ePO data (step 10). The supplier eInvoice is routed via the HUB to the contractor's invoice workbench on the ERP software (step 11).

While it is clear that the re-designed process has potential to remove the inefficiencies highlighted earlier, it was, nevertheless essential to test the process in a live site environment.

No particular lessons were identified by the contractor's parties, other than the fact that the pilot project results proved that the re-engineering concept and the technology worked. The decision to invest in the technology by the contractor, however, will depend on a sufficient number of their suppliers investing in the use of this technology also. The supplier's representative was considering investing in the technology, however, similar to the contractor's representatives, they would like to see more of their supply chain adopting this technology in order to defray the set up and annual maintenance costs. The supplier's representative was convinced that the contractor's re-keying would be significantly reduced with a minimal possibility of errors between PO, delivery notes and supplier invoices. From the supplier's perspective, this will lead to significantly less queries and faster payment. The solution provided the supplier with the confidence that the 30 days credit target could easily be achieved, however, there may be some reluctance in the marketplace, in particular from contractors to becoming more efficient in their payment cycles.

The authors found that the time saving could conservatively lead to a potential saving of $€ 10,000$ per annum for the contractor. It is important to appreciate that the pilot supplier was a relative small volume supplier to contractor, in comparison to others. The contractor reported that there were 596 POs between the two companies in 2006. The more suppliers that invest in the technology and that trade with the contractor, the greater the potential savings for the contractor.

The vast majority of original objectives, identified earlier, were fully achieved. Table 1 summarises the achievements of the pilot project objectives.

Table 1. Achievement of the pilot project objectives

\begin{tabular}{|l|l|}
\hline Pilot Project Objectives & Observations \\
\hline $\begin{array}{l}\text { To document the current } \\
\text { trading procedures utilised } \\
\text { within the contractor's or- } \\
\text { ganisation. }\end{array}$ & $\begin{array}{l}\text { This was the first step in the re- } \\
\text { engineering process This in- } \\
\text { volved mapping the process flow } \\
\text { charts for the material ordering, } \\
\text { material receiving and invoice } \\
\text { processing. }\end{array}$ \\
\hline $\begin{array}{l}\text { To identify the inefficien- } \\
\text { cies that currently exist } \\
\text { within the contracting or- } \\
\text { ganisation. }\end{array}$ & $\begin{array}{l}\text { The key inefficiencies observed } \\
\text { included manual work, re-keying } \\
\text { of information and extensive } \\
\text { photocopying. }\end{array}$ \\
\hline $\begin{array}{l}\text { To re-design the purchas- } \\
\text { ing process with a view to } \\
\text { addressing the inefficien- } \\
\text { cies that currently exist. }\end{array}$ & $\begin{array}{l}\text { The focus for re-designing the } \\
\text { process was the source of the PO } \\
\text { information. The logic involved } \\
\text { maintaining a single original } \\
\text { sources for all purchasing docu- } \\
\text { ment which would in turn allow } \\
\text { for an electronic matching of the } \\
\text { original PO, GRN and supplier } \\
\text { invoice. }\end{array}$ \\
\hline $\begin{array}{l}\text { To document the proposed } \\
\text { re-engineering process on } \\
\text { a live project. }\end{array}$ & $\begin{array}{l}\text { The proposed ICT infrastructure } \\
\text { to be adopted involved the elec- } \\
\text { tronic transfer of PO, delivery } \\
\text { to be utilised between the } \\
\text { contractor and the supplier } \\
\text { on the intended pilot pro- } \\
\text { ject. } \\
\text { notes and invoices via a central } \\
\text { web-based repository. }\end{array}$ \\
$\begin{array}{l}\text { transactions carried out in Octo- } \\
\text { ber and December 2006 between } \\
\text { the contractor and the supplier, } \\
\text { with a 100\% success rating on } \\
\text { the matching of the PO, delivery } \\
\text { note and the invoice. }\end{array}$ \\
\hline
\end{tabular}

It can be seen in Table 1 that all the 2006 pilot project objectives were successfully achieved.

The process of educating the industry about the benefits of eCommerce has involved a number of research methodologies since 2002. It began with the authors undertaking observation studies and studies in 2002 and again in 2006 (Hore and West, 2005a). The findings from these studies clearly 
demonstrated the need for current purchasing processes to be re-engineered to introduce efficiencies and to enhance the audit trails associated with the various activities that are undertaken in the supply chain. During the period 2002 to 2006, there were two studies undertaken which demonstrated that the technology necessary for implementing a electronic supply chain exists and could be deployed successfully in the construction industry (Hore and West, 2005b, 2005c,2005d and 2005e).

\section{CITA E-COMMERCE GROUP}

For the past two years CITA have been working on the CITA eXchange (CITAX) project which sought to verify that significant measurable economic benefits can be achieved by collaborating trading network members by the use of existing ICT standards in their business processes (DETE, 2006, West and Hore, 2007 and EC, 2007).

In 2006, CITA was successful in applying for funding from Enterprise Ireland, a state agency that is responsible for the development of indigenous Irish industry, to support a project that seeks to review and/or develop standards for the electronic exchange of information between interested parties in the construction industry. The funding has enabled CITA to create a project called CITAX (Construction IT Alliance exchange) that is organised into five modules, one of which is examining eCommerce, while the others deal with the exchange of drawings, electronic tendering, project collaboration and computer aided measurement (West and Hore, 2007).

The CITAX project focused on five module areas:

- Module 1 - Production and exchange of CAD drawings.

- Module 2 - Production and exchange of trading documentation, such as purchase orders, goods received notes and invoices.

- Module 3 - The pricing of tender documentation electronically and recommendation of a preferred tender for selection.

- Module 4 - The storage, retrieval and general dissemination of project information on construction projects.

- Module 5 - The use of CAD software in the production of bills of quantities.

Each module involved a Project Leader drawn from industry together with a cross section of com- panies from different disciplines, including the support of an academic institution.

The module 2 team focused on the following objectives:

1. Develop a universally acceptable XML standard for electronic exchange of purchase orders, delivery notes and supplier invoices.

2. Demonstrate, by participation in a live pilot project, that purchasing data transactions can be more efficiently exchanged between trading network members by the adoption of the XML standard.

The existing supply chain process has been evaluated and a cost model developed to allow individual organisations estimate how much the traditional supply chain process is costing them. The team has also developed a revised business process based on exchanging transactions electronically, and has also developed a revised cost model that allow organisations to establish the savings that they can achieve through eCommerce. A pilot project is underway to prove that the savings identified by the team in the course of its work can be achieved when the technology is implemented in practice.

One of the most significant challenges for the CITAX module 2 team was how to tailor-make a suitable XML standard that would be acceptable to the vast majority of players in the Irish construction sector, especially as many traders are small enterprises. For the adoption of a common XML to be widespread, it was important that the companies participating in the project would define and agree sets of message sets for each of the stages of the trading process.

XML standards have been developed in several industries, such as business, retail and also the building and construction industry. For example, the Building and Construction XML (bcXML) (Toleman et al., 2001), Electronic Business XML (ebXML) (Lima et al., 2003) and Industry Foundation Classes XML (ifcXML) (Froese, 2003). These standards are essentially shared vocabularies and rules for defining the structure, content and meaning of similar XML documents. XML is extensible because each element of data is separately identified, all of the elements do not have to be present in the message, only the elements that are required by the message definition, the XML schema.

The module team identified a number of messaging formats that needed to be agreed among the participating companies, with the intention of developing a CITAX XML Trading standard (see Table 2).

Table 2. CITAX Module 2 XML Message Formats 


\begin{tabular}{|c|c|}
\hline $\begin{array}{l}\text { Message } \\
\text { Type }\end{array}$ & Message Content \\
\hline Order & $\begin{array}{l}\text { Order messages are created by the contractor } \\
\text { and sent to the supplier. }\end{array}$ \\
\hline $\begin{array}{l}\text { Order Con- } \\
\text { firmation }\end{array}$ & $\begin{array}{l}\text { On receipt of an order from a contractor, it is } \\
\text { created/saved on the supplier's system. Con- } \\
\text { firmation of the details recorded/received is } \\
\text { transmitted back to the supplier. This can in- } \\
\text { clude out of stock notifications. This message } \\
\text { can also be used to create an order on the con- } \\
\text { tractor's system if it has not been recorded } \\
\text { there previously. }\end{array}$ \\
\hline $\begin{array}{l}\text { Order Can- } \\
\text { cellation }\end{array}$ & $\begin{array}{l}\text { Used to cancel an order that had previously } \\
\text { been sent through from the contractor. }\end{array}$ \\
\hline $\begin{array}{l}\text { Shipping } \\
\text { Notice }\end{array}$ & $\begin{array}{l}\text { An Electronic Shipping Notice (eSN) is an ad- } \\
\text { vice from the supplier to the contractor listing } \\
\text { the items that are to be delivered. It is effec- } \\
\text { tively the supplier's dispatch note and is } \\
\text { transmitted in advance of the delivery as soon } \\
\text { as the dispatch details have been verified by } \\
\text { the supplier. }\end{array}$ \\
\hline POD & $\begin{array}{l}\text { A POD (Proof of Delivery) is a document that } \\
\text { lists items delivered together with the contrac- } \\
\text { tor's signature, captured electronically. It is } \\
\text { the basis on which contractors can be invoiced } \\
\text { for items delivered. }\end{array}$ \\
\hline GRN & $\begin{array}{l}\text { A GRN (Goods Received Note) is the contrac- } \\
\text { tor's equivalent of the POD, i.e. it shows from } \\
\text { a contractor's perspective what was delivered } \\
\text { to site. }\end{array}$ \\
\hline Invoice & $\begin{array}{l}\text { Document that charges the contractor for items } \\
\text { delivered. }\end{array}$ \\
\hline Credit Note & $\begin{array}{l}\text { Document that credits the contractor account } \\
\text { for items such as pricing corrections; credit for } \\
\text { items not received; or credit for damaged } \\
\text { items. }\end{array}$ \\
\hline
\end{tabular}

Having reviewed the standards available, the team chose to use as a base the BASDA eBuild XML standard. A variety of other standards were reviewed such as EDI and GS1 XML, but the eBuild XML standard is currently used widely in the UK construction industry, although there are a number of new messages that will have to be developed by CITA, particularly for PODs and GRNs. It has also become apparent that the proliferation of standards means that each organisation that trades electronically has to have a flexible system that caters for all of the other standards in the marketplace. The possibility of universal buy-in to one common XML schema, though difficult to achieve, has obvious advantages and is vital to successful industry-wide implementation.

The module team are currently organising the pilot or testing phase, engaging with software users and vendors. Presently there are two pilot projects underway that will adopted the eBuild XML standard. The unwillingness of some software vendors to interoperate with other software companies is a very significant hurdle that has to be overcome by the industry.
Preliminary findings from the project demonstrate that there are significant opportunities for increased efficiency and effectiveness in the industry. A strong business case has been made for ICT adoption, through:

1. Accelerating the industry adoption of CAD standards, electronic commerce, electronic tendering, electronic collaboration and computer aided measurement within the Irish construction industry.

2. Accelerating the industry adoption of product data standards sets that will support electronic commerce activity within the Irish construction industry.

3. Accelerating the adoption of interoperable building information model-based software through testing and demonstration.

4. Establishing methods that facilitate the harmonisation of existing building information modelling and bring consistency to the construction industry's efforts to integrate the supply chain with common information models.

5. Assisting the Irish construction industries in developing and implementing interoperability standards and work process improvements that reduce the life cycle time, costs and risks.

\section{IMPLEMENTATION OF ICT COMMUNICATION STANDARDS IN IRELAND}

Having demonstrated the business case for both contractors and suppliers to adopt ICT in their conversion to e-commerce practices, the key to success in implementing any ICT standards involves reaching cross-community agreement on a willingness to participate through:

1. A strong commitment from leading construction industry companies to collectively rather than individually take a lead and actively participate in the implementation.

2. Demonstration of the potential impact of ICT standards in

○ Creating a step-change in communication efficiency for all parties to the supply chain

- Developing new or adoption of existing international standards

3. A willingness of suppliers to adopt the new XML standards for document exchange in their purchasing software and to invest in 
developing a supplier-specific product code database for ordering.

4. An openness of all major software vendors associated with participating contractors and suppliers to alter their software to accommodate the new XML standard. The work undertaken by the software vendors must be financed by the demonstrable efficiency gains of the contractors and suppliers on implementation of the new e-purchasing practices.

An example includes creating generic codes for products to which both suppliers and buyers would map their product codes. This would mean that buyers and suppliers would only have to map their codes once. Through the CITA eCommerce group a wide platform has been created which has facilitated dialogue between these three parties, which otherwise would not have been possible.

The methodology currently adopted by the CITA eCommerce group includes:

1. Secure contractor and supplier commitment within the Irish construction supply chain.

2. Establish a steering group to manage the direction of eCommerce implementation.

3. Agree infrastructure for messaging formats and exchange mechanisms.

4. Establish CITA project management support.

5. Initiate implementation programme with steering group members.

6. Rollout implementation across the industry.

The challenges facing the Irish construction include:

O develop tools, protocols and standards which are non-proprietary and which facilitate interaction between participants in the industry.

- define and promote standards in data communications.

$\bigcirc$ through piloting, measurement and demonstration, promote building information modelling across the industry.

○ identify and design services and products which will enable the participants in the industry to work collaboratively through the supply chain in Ireland and internationally.

Despite these challenges, it is likely that the industry will begin adopting ICT standards in the short term, although it is recognised that it will take time to filter through the entire industry. The adoption of e-procurement by a sufficient threshold of parties is likely to catalyse others in the market be- cause the use of e-procurement will be seen as a providing competitive edge, much as quality assurance schemes did in the 1990s.

\section{CONCLUSION}

The overall aim of the pilot project was to reengineer the purchasing process within a contractor's organisation, by enabling an electronic threeway match of the PO, delivery docket and invoice data, thus enabling a significant improvement in both productivity and overall administration costs per transaction. In order to verify that the process has been successfully re-engineered, Li (1996) suggested that an evaluation of the results must indicate that the re-engineering goals were achieved.

The goal of achieving a paperless process was largely achieved with an acknowledgement that some paper is a necessary ingredient of any business process. A sophisticated level of integration was achieved between the ICT tools deployed in the pilot project, with an end-to-end seamless population of data between both trading partner's ICT systems. There was no incidence of mislaid documentation being reported throughout the pilot project period. There was only a limited degree of re-keying of information by the contractor's staff during the matching process, namely, in order to verify receipt of the electronic information. The ultimate goal of achieving a three-way electronic match of the PO, delivery docket and the supplier invoice was fully realised. These results show clearly that significant productivity improvements and potential savings are achievable for the wider construction industry should this re-engineered solution be deployed (Hore, West and Gunnigan, 2004).

A measure of the success of the current project can be seen in the response of the industry to the work that has been undertaken to-date. Even before the project has completed its work, 11 major Irish contractors have expressed an interested in investigating the implementation of eCommerce into their own organisations. They have asked for expressions of interest from their suppliers in working with them on this and this approach has been met positively by the initial set of approximately 25 supplier companies that have been asked to participate. The expected results include the setting up of a dedicated eCommerce group by CITA to provide independent advice and support to the members that are embarking on implementing eCommerce. An additional expected results will be the implementation of a standard data pool to facilitate the interoperable exchange of product codes between trading partners which is presently ongoing. 


\section{REFERENCES}

Canter, M.R., (1993), Resource Management for Construction, Macmillan.

Department of Finance (DoF), (2002), Strategy for the Implementation of eProcurement in the Irish Public Sector, Irish Government Publications.

Department of Enterprise, Trade and Employment (DETE), (2006), "Implementing the National eBusiness Strategy of the Department of Enterprise Trade and Employment", Government Publication, Ireland.

European Commission, (2007), Benchmarking sectoral e-Business Policies in Support of SMEs: Innovative approaches, good practices and lessons to be learned, Study by Empirical, Databank and Idate.

Froese, T. (2003). "Future directions for IFC-based interoperability", Electronic Journal of Information Technology in Construction, 8, 231-246.

Gunnigan, L., Orr, T.L.L. and Hore, A.V., (2004), 'Rationalising the construction materials purchasing process', The International Salford Centre for Research and Innovation (SCRI) Research Symposium and International Built and Human Research Week, Salford University, Manchester, 376-385.

Hore, A.V. and West, R.P., (2004), 'A Proposal for re-engineering the procurement of building materials by effective use of ICT', Incite 2004 Conference, Designing, Managing and Supporting Construction Projects Through Innovation an IT Solutions, Langkawi, Malaysia, 375-380.

Hore, A.V., West, R.P. and Gunnigan, L., (2004), 'Enabling the re-engineering of material purchasing in the construction industry by the effective use of information technology', The International Salford Centre for Research and Innovation (SCRI) Research Symposium and International Built and Human Research Week, Salford University, Manchester, 386-395.

Hore, A.V. and West R.P. (2005a), "Attitudes towards electronic purchasing in the Irish construction industry”, CIB W92/T23/W107 International Symposium on Procurement Systems, Las Vegas, USA.

Hore, A.V. and West, R.P. (2005b), 'Realising electronic purchasing in the Irish Construction Industry', Combining Forces - Advanced Facilities Management \& Construction Through Innovation Conference, Helsinki, June 2005, 154 - 166.

Hore, A.V. and West, R.P. (2005c), 'Benefits of deploying IT in the material procurement of ready-mix concrete in the Irish Construction Industry', Concrete Research in Ireland Colloquium 2005, University College Dublin, 14-15 December, 71-80.

Hore, A.V. and West, R.P., (2005d), 'Realising electronic purchasing in the Irish Construction Indus- try', Combining Forces - Advanced Facilities Management \& Construction Through Innovation Conference, Helsinki, June 2005, 154 - 166.

Hore, A.V., and West, R.P., (2005e), 'A survey of electronic purchasing practice in Ireland: a perspective for the Irish construction industry', the $2^{\text {nd }}$ International Salford Centre for Research and Innovation (SCRI) Research Symposium and International Built and Human Research Week, Salford University, Manchester, 98-108.

West, R.P. and Hore, A.V., 2007, "CITAX: Defining XML standards for data exchange in the construction industry supply chain", Bringing ICT Knowledge to Work, 24th W78 CIB conference, Maribor 2007, 5th ITCEDU Workshop and 15th EC-ICE Workshop, Slovenia: Maribor, 26-29th September, 217-224

Li, H., (1996), The Role of IT Manager in Construction Process Re-engineering, Building Research and Information, 24, 124-128.

Lima, C., Stephens, J. and Bohms, M., (2003), "The BCXML: supporting e-commerce and knowledge management in the construction industry", Electronic Journal of Information Technology in Construction, 8, 293-308.

O'Leary, D.E., (2000), Supply chain processes and relationships for electronic commerce, Handbook on Electronic Commerce, Springer 2000, 431-444.

Tavakoli A, Kakalia A. MMM: A materials management system, Construction Management and Economics. 1993; 11, 143-149.

Thomas, K. and Hore, A.V., (2003), 'A reflection on the development, activities and deliverables of the Construction IT Alliance (CITA) in Ireland', $C I B$ W89, International Conference on Building Education and Research, 9-11 April, 506-517.

Tolman, F., Bohms, M., Lima, C., Van Rees, R., Fleur, J. and Stephens, J., (2001), "E-construct: expectations, solutions and results", Electronic Journal of Information Technology in Construction, 6, 175-197.

West, R.P. and Hore, A.V. (2007), "CITAX: Defining XML standards for data exchange in the construction industry supply chain", Bringing ICT Knowledge to Work, 24th W78 CIB conference, Maribor 2007, 5th ITCEDU Workshop and 15th EC-ICE Workshop, Slovenia: Maribor, 26-29th September. 